\title{
Forensic Accounting and Compliance Audit to Reduce the Number of Financial Fraud in Local Government
}

\author{
Anggriyani $^{1}$, Muhammad Yusuf $^{2}$, Kornelius Harefa ${ }^{1}$ \\ ${ }^{1}$ Accounting Program, Faculty Economic, Universitas Negeri Medan, North Sumatera \\ ${ }^{2}$ Economics Program, Faculty Economic, Universitas Negeri Medan, North Sumatera \\ *Corresponding Author(s) Email : anggriyani@ unimed.ac.id
}

\begin{abstract}
One of the corruption cases that has been revealed by the BPK is the Century Bank case. Report The results of a follow-up investigation (forensic audit) conducted by the Supreme Audit Agency of the Republic of Indonesia on PT Bank Century Tbk, strengthen the results of the previous examination (stage I investigative audit) which revealed allegations of state financial losses. The case of the loss of Bank Century money handled by the BPK is one of the frauds that is categorized as a white collar crime. These cases were carried out by people who have positions and authority to make vital decisions so that it is not easy for BPK to uncover the case. In breaking up the Century Bank case, BPK used an advanced investigative method (forensic accounting) because this method was considered to be able to examine in detail, be more in-depth and reliable in uncovering white collar crime cases. The use of the combination of investigative auditing and forensic accounting as a follow-up to the weaknesses found in the design and implementation of the fraud control plan as well as the complaints received is the use of careful accounting audit techniques and methods, sharp logic and problem analysis, as well as creativity and innovation in thinking. The samples taken were all 33 districts in North Sumatra Province. Data is taken secondary data. The results of the qualitative discussion of the secondary data collected show that the use of fraud detection with audit investigations and forensic accounting is very useful so that fraud can be found correctly. Relevant parties such as Bawasda or regional Inspectorates, BPKP, BPK, ICW and the KPK collect data and sufficient evidence so that the data obtained can be strong enough to support in conveying that the Regency Government or Regent committed fraud. Submitting quarterly, semi-annual, and annual Budget and Expenditure data collection provided by the Regency Government so that the data is neatly organized and interconnected and easy to control.
\end{abstract}

Keywords: White collar crime cases, Forensic Accounting, Audit Investigative, white collar crime cases

\section{INTRODUCTION}

The Supreme Audit Agency of the Republic of Indonesia, abbreviated as BPK RI, is a high state institution in the Indonesian constitutional system which has the authority to examine the management and responsibilities of state finances. The audit of the BPK is carried out on the central government, regional governments, other state institutions, Bank Indonesia, state-owned enterprises/agencies. regional-owned enterprises, public service agencies, and other institutions or bodies that manage state finances. The audits referred to include financial audits, performance audits, and audits with specific objectives. Based on the Summary of Semester Examination Results (IHPS) I of 2016 was compiled to comply with the provisions of Article 18 of Law Number 15 of 2004. This summary is a summary of the 696 Audit Results Reports (LHP) completed by BPK in the first semester of 2016.

These LHPs include 116 LHP (17\%) for the central government, 551 LHP (79\%) for local governments, and 29 LHP (4\%) for State-Owned 
Enterprises (BUMN) and other entities. Based on the type of audit, the LHP consists of 640 LHP (92\%) financial, 8 LHP (1\%) performance, and 48 LHP (7\%) with a specific purpose. The results of the BPK

problems of non-compliance with the provisions of laws and regulations amounting to Rp44.68 trillion.

The non-compliance problems, as many as 4,762 $(60 \%)$ were problems with a financial impact of IDR 30.62 trillion. Summary of Examination Results of Semester I 2016 IHPS I 2016 xxii the details are as follows:

1. State losses amounted to $3,163(66 \%)$ problems worth Rp1.92 trillion.

2. The potential loss to the state is $421(9 \%)$ problems worth IDR 1.67 trillion.

3. Shortage of revenue as many as $1,178(25 \%)$ problems amounting to Rp27.03 trillion.

In addition, there were $3,145(40 \%)$ noncompliance issues that did not have a financial impact, consisting of 2,985 (95\%) administrative irregularities and $160 \quad(5 \%)$ ineffectiveness, inefficiency, and ineffectiveness worth Rp14.06 trillion. On the issue of non-compliance that has a financial impact, at the time of inspection, the audited entity has followed up by handing over assets or depositing it into the state treasury in the amount of Rp442.24 billion (1\%).

The Summary of Semester Examination Results (IHPS) II of 2016 was prepared to comply with the provisions of Article 18 of Law Number 15 of 2004. This summary is a summary of the 604 Audit Results Reports (LHP) completed by BPK in the second semester of 2016. The LHP includes 81 LHP (13\%). Based on the type of audit, the LHP consists of 9 LHP (1\%) financial, 316 LHP (53\%) performance, and 279 LHP (46\%) with a specific purpose (PDTT). The results of the BPK examination in the second semester of 2016, BPK revealed 5,810 findings containing 7,594 problems, including 1,393 (18\%) SPI weaknesses and 6,201 (82\%) problems of noncompliance with statutory provisions amounting to Rp19.48 trillion.

Of the non-compliance problems, 1,968 (32\%) were problems with a financial impact of Rp12.59 trillion. The details are as follows: examination in the first semester of 2016, BPK revealed 10,198 findings containing 15,568 problems, including 7,661 (49\%) weaknesses of the SPI and 7,907 (51\%)

1. State losses amounted to 1,205 (61\%) problems amounting to Rp1.37 trillion.

2. The potential loss to the state is $329(17 \%)$ problems worth Rp6.55 trillion.

3. Lack of revenue as many as 434 (22\%) problems worth Rp4.66 trillion.

In addition, there were 4,233 (68\%) noncompliance issues that did not have a financial impact, consisting of $617(14 \%)$ administrative irregularities and 3,616 (86\%) ineffectiveness, inefficiency, and ineffectiveness worth $\mathrm{Rp} 6.88$ trillion. On the issue of non-compliance with a financial impact of Rp12.59 trillion, at the time of the examination, the audited entity had followed up by handing over assets or depositing it into the state treasury of Rp130.78 billion (1.03\%). This shows that fraud is not a deviation that occurs by chance or negligence, but is related to the planning process. Eradication that is repressive in nature, taking action against corrupt practices after the incident has occurred, is less effective in eradicating corrupt practices because they have to mobilize more resources, take longer and the process is not easy. In addition, corrupt practices have resulted in losses to the state's finances and the economy.

One of the corruption cases that has been revealed by the BPK is the Century Bank case. Report The results of a follow-up investigation (forensic audit) conducted by the Supreme Audit Agency of the Republic of Indonesia on PT Bank Century Tbk, strengthen the results of the previous examination (stage I investigative audit) which revealed allegations of state financial losses.

The chairman of the BPK, Hadi Poernomo, emphasized that the 13 findings from the follow-up investigation were one unit with the nine findings in the report on the results of the first phase of the investigation. Especially in terms of the flow of funds of Rp 6.7 trillion. [2]. The case of the loss of Bank Century money handled by the BPK is one of the frauds that is categorized as a white-collar crime. These cases were carried out by people who have positions and authority to make vital decisions so 
that it is not easy for BPK to uncover the case. In breaking up the Century Bank case, BPK used an advanced investigative method (forensic audit) because this method was considered to be able to examine in detail, be more in-depth and reliable in uncovering white collar crime cases.

The use of the investigative audit method as a follow-up to the weaknesses found in the design and implementation of the fraud control plan as well as the complaints received is the use of careful accounting audit techniques and methods, sharp logic and problem analysis, as well as creativity and innovation in thinking.

North Sumatra Governor (Gubsu) Edy Rahmayadi stated that the impact of corruption in North Sumatra has so far become the area with the fourth most corruption cases according to the KPK version. Edy said that it was corruption that caused poverty in North Sumatra which he judged to be rich in resources but why the management was wrong [4].

The use of the investigative audit method as a follow-up to the weaknesses found in the design and implementation of the fraud control plan as well as the complaints received is the use of careful accounting audit techniques and methods, sharp logic and problem analysis, as well as creativity and innovation in thinking.

If indications of fraud have been found by state officials, Forensic Accounting is needed in the form of evidence that strengthens those who arrest and prosecute officials who are suspected of committing judicial fraud to conduct trials before the law.

\subsection{Formulation of the problem}

Based on the background of the problems mentioned above, the formulation of the research problem is:

1. Is there any effect of Forensic Accounting on fraud?

2. Is there an Influence of Compliance Audit on Fraud

\subsection{Research Objectives and Benefits}

Research Objectives are:

\section{The Effect of Forensic Accounting on Fraud}

\section{Effect of Compliance Audit on Fraud}

The benefit of this research is for academic studies on forensic accounting, compliance audits and fraud that will affect fraudulent behavior. Another academic impact is on the teaching of Compliance and Fraud Forensic Accounting.

\section{LITERATURE REVIEW}

\subsection{Cheating (Fraud)}

Fraud as a criminal act that is well known for cunning, manipulation, or breach of trust that does not result in threats or physical violence. This fraud is carried out by other parties involved to obtain money, property, or services; to avoid loss of services, or to secure personal or business gain.

Bologna et al. [5] define fraud as a criminal fraud that intends to provide financial benefits to the fraudster. Crime here means any act of serious wrongdoing committed with malicious intent. And from these evil actions he derives benefits and harms his victims financially.

The idea of the impetus that causes fraud or better known as the Fraud Triangle Theory. These impulses are classified into three general categories, namely:

\section{Pressure}

Most individuals need some form of pressure to commit a criminal act. The pressure can be in the form of financial problems, gambling debts, drug or drug addiction, excessive medical costs.

\section{Opportunity}

In the case of fraud, usually a temporary situation arises because there is an opportunity to commit a criminal act without a high probability of being caught. Companies that do not work actively in preventing fraud can create repeated opportunities for individuals who meet the three criteria for the fraud triangle.

\section{Justification (Rationalization)}

Thoughts of people who do unethical actions are also one of the justifications. Some will think that they just borrowed the stolen item, or think 
that they need more money than the company needs, so they will assume that their actions are not wrong.

There are three types of fraud based on actions, namely:

1. Asset Misappropriation is a deviation from assets. This type of fraud is a classic type of fraud and is the easiest to detect because it is tangible or can be measured and calculated.

2. Fraudulent statements are statements or reports that are deceptive or false. The perpetrator in a fraudulent statement is usually a manager because the majority of the perpetrators are at the managerial level, which are officials or executives and senior managers.

3. Corruption is a fraud that is very difficult to detect. This type of fraud is carried out in collaboration with other parties, or what is commonly referred to as collusion.

Fraud (fraud) in the business environment is classified into five types, namely:

1. Employee embezzlement or occupational fraud

Is a type of fraud committed by subordinates to superiors. This type of fraud is carried out by subordinates by cheating on their superiors directly or indirectly.

\section{Management fraud}

Is a type of fraud committed by top management to shareholders, creditors and other parties who rely on financial statements. This type of fraud is carried out by top management by providing a misrepresentation, usually in financial information.

\section{Investment scams}

Is a type of fraud committed by individuals / individuals to investors. This type of fraud is carried out by individuals by tricking or deceiving investors by investing their money in the wrong investments.

\section{Fraud vendors}

Is a type of fraud committed by organizations or individuals who sell goods or services to organizations or companies that also sell goods and services. This type of fraud is carried out by organizations by setting prices too high for goods and services or not delivering goods even though payment has been made.

\section{Customer fraud}

Is a type of fraud committed by customers to organizations or companies that sell goods or services. This type of fraud is carried out by customers by deceiving the seller by giving to the customer what they shouldn't or accusing the seller of giving less than they should.

\subsection{Financial statements}

The financial condition and results of the company's operations which are reflected in the company's financial statements are essentially the final result of the company's accounting activities.

Financial statements are "after transactions are recorded and summarized, reports are prepared for users." Accounting reports that produce such information are called financial statements. The main financial statements for a company are the income statement, owner's equity statement, balance sheet, and cash flow statement.

According to PSAK No. 1 (2015:1), "Financial statements are a structured presentation of the financial position and financial performance of an entity." This report displays the history of the entity quantified in monetary value.

Users of financial statements include current and potential investors, employees, lenders, suppliers and other business creditors, customers, governments and their institutions, and the public. They use financial statements to meet different information needs. Some of these information needs include:

1. Investors. Risky investors and their advisors are concerned with the inherent risk and development returns of their investments. They need information to help determine whether to buy, hold, or sell the investment. Shareholders are also interested in information that allows them to value companies for paying dividends.

2. Employees. Employees and other groups that represent them are interested in information about the stability and profitability of the company. They are also interested in information that allows them to assess the 
company's ability to provide remuneration, post-employment benefits, and employment opportunities.

3. Lenders. Lenders are interested in financial information that allows them to decide whether loans and interest are payable when they fall due.

4. Suppliers and other business creditors. They are interested in information that allows them to decide whether amounts owed will be paid when they fall due. Business creditors have an interest in the company in a shorter period of time than the lender, unless as a Customers.

5. Customers are interested in information about the viability of the company, especially if they are involved in long-term agreements with, or depend on, the company.

6. Government. The government and various institutions under its control have an interest in the company's activities. They also need information to regulate corporate activities, establish tax policies, and as a basis for compiling national income statistics and other statistics.

7. Society. Companies influence members of society in a variety of ways. Financial reports can help the public by providing information on trends (trends) and the latest developments in the prosperity of the company and its series of activities.

The objective of the financial statements according to PSAK No. 1 is to provide information about the financial position, financial performance, and cash flows of an entity that is useful for most users of the report in making economic decisions.

Some of the qualitative characteristics of accounting information according to SFAC No. 2:

1. Relevance.

Able to make a difference in decisions by helping users to form predictions about the outcome of past, present, and future events or to confirm or correct expectations. Relevance has 2 main aspects and 1 additional aspect, namely:

a. Predicted value. Refers to the usefulness of the input from the prediction, for example, cash flow or profitability. Compared to being his own prediction. b. Feedback value. Emphasis on confirmation or correction of the initial expectations of the decision makers. To estimate where the company's current position is and how management is carrying out its duties. If viewed more broadly, the value of this feedback is related to accountability. The information that this value provides also affects the predicted value.

c. Punctuality. It is an obstacle to the previous two aspects. To be relevant, the information must be timely, which must be available to decision makers before the information loses its capacity to influence decisions.

2. Reliable.

It is divided into 3 parts, namely:

a. Can be verified. Referring to previous documents, on the level of consensus among the gauges. Unlike the relevance aspect, there is an element of quantity to be verified.

b. Honest presentation. This is also related to the theory of measurement. Refers to the notion that the measurement itself must be in accordance with the phenomenon to be measured. It is clear, however, that there can easily be a conflict between reliability and fairness of presentation, and the need to make trade-offs between the two characteristics of reliability may arise.

c. Neutral. Refers to the belief that the rule setting process should be concerned primarily with relevance and reliability rather than the effect that standardized rules may have on specific user groups. In other words, neutrality relates to financial statements "stated that way" rather than how other groups want the financial statements to be prepared.

\subsection{Financial Statement Fraud}

Financial statement fraud is a deliberate misstatement or dedication of amounts and disclosures to deceive report users. Fraud is often done in a company to make a profit and attract other investors. Financial statement fraud in the form of setting higher or lower on assets or profits of a company can be done in various forms. The determination of a company's assets/profits is higher or lower in five ways, namely: 


\section{Fraud in asset valuation}

Inappropriate asset valuations mostly include fraud in the theft of company cash either petty cash or cash receipts and fraud in company expenses such as check fraud, as well as overstating inventory and accounts receivable. In addition, it also includes cheating on the purchase price of assets, recording fictitious assets, misclassification of fixed assets, improper capitalization of inventories. This of course will result in an increase in company profits.

\section{Fictitious income}

Namely by recording the sale of goods or services that did not actually occur. This will certainly benefit the company's financial position because it results in an increase in the company's assets and revenues.

3. Concealment of company obligations and expenses

Setting lower liabilities and expenses is one way of manipulating financial statements to make a company appear more profitable. This can be done by not recording or hiding transactions related to the company's obligations and expenses, capitalizing expenses, and inadequate disclosure of guarantee costs.

4. Time difference in recognizing revenue

That is by recording revenue prematurely (recognizing revenue immediately or earlier than before the sales activity is completed).

5. Fraud in the disclosure of financial statement information

Fraudulent disclosure of financial statement information usually includes concealment of obligations, future events, management fraud, related transactions, and changes in the company's accounting policies.

\subsection{White Collar Crime}

White-collar crime is a very well-known term in English, namely white-collar crime. The term was introduced by Edwin H. Sutherland in December 1939 when he delivered his inaugural address as chairman of the American Sociological Society in Philadelphia.
Clinard and Quinney [6] divide white collar crime into two divisions, namely:

1. Occupational crime: Crimes committed for the benefit of the organization, crimes committed as a result of state power, crimes committed by professionals in their work capacity, and crimes committed by individuals for personal gain.

2. Corporate crime: Administrative violations, environmental violations, financial violations, labor violations, manufacturing violations, and dishonest trading practices

Some characteristics of white collar crime that distinguish it from other crimes, namely:

1. Perpetrators are difficult to identify. If the damage has not been felt, the victim will not be conscious.

2. It takes a long time to prove and also requires certain skills.

3. When it comes to organization, it is difficult to find someone who is responsible, usually directed to superiors for not preventing them, or to subordinates for not following orders from superiors.

4. The victimization process is also disguised because the perpetrator and the victim do not face each other directly.

5. The complexity and covertness of the perpetrators make it difficult to track down.

6. Difficult to prosecute due to lack of evidence and who is to blame.

7. Perpetrators usually get light treatment or sanctions.

8. Perpetrators usually have ambiguous criminal status.

\subsection{Forensic Accounting}

According to the opinion expressed by Tuanakotta [11] forensic accounting is the application of accounting discipline in a broad sense, including auditing on legal issues for legal settlement inside or outside the court.

\subsection{Investigation Audit}

Tuannakotta [11] suggests that audit investigations and fraud examinations are used interchangeably as synonyms. Ideally there is a similarity in meaning between the concepts of 
auditing and law. However, in terms of auditing philosophy and legal philosophy, this is not possible.

K.H Spencer Pickett and Jennifer Pickett in Tuanakotta [11] formulate several standards for those who investigate fraud. This standard will be explained in the Indonesian context:

1. All investigations must be based on accepted best practices. The term best practice is often used in setting standards. This term implies two things, namely an effort to compare existing practices with reference to the best at that time, and benchmarking efforts are carried out continuously to find the best solution.

2. Collecting evidence with the principles of due care so that the evidence can be accepted in court.

3. Ensure that all documentation is safe, protected, and indexed; and audit trail available. This documentation is needed as a reference if there is a future investigation to ensure that the investigation has been carried out properly. This reference also helps companies in their efforts to improve investigative methods so that the accepted best practices described above can be implemented.

4. Noting that investigators understand the human rights of employees and always respect them. If the investigation is carried out in a way that violates the human rights of employees, the person concerned can sue the company and its investigators. The evidence that has been collected with a lot of time and money is wasted.

5. Bearing in mind that the burden of proof rests with the company that "suspects" its employees of committing fraud, and on the public prosecutor who has accused the employee, both in administrative and criminal law cases.

6. Cover the entire substance of the investigation and "master" all targets that are very critical in terms of time.

7. Covers all key stages in the investigative process, including planning, gathering evidence and evidence, interviews, contact with third parties, confidential security, following procedures or protocols, documentation and record keeping, police involvement, legal obligations, and requirements regarding reporting.
Application of Forensic Accounting and Investigation Audit in the Detection of White Collar Crime.

Fraud in Indonesia is a big problem faced by accountants or auditors today. The resolution of these cases is not easy but must go through appropriate procedures to obtain strong evidence. Forensic accounting and investigative audits are one way to detect fraud because this investigative audit includes things that can detect fraud that has occurred or is currently happening [1]. This investigative audit is carried out using the same audit technique as the financial statement audit technique, by conducting an investigative audit, investigators can obtain certainty whether the suspect is really wrong or not [9]. Audit techniques are the methods used in auditing the fairness of the presentation of financial statements. The result of applying audit techniques is audit evidence. There are seven techniques, which are detailed in the form of Indonesian verbs, with the type of audit evidence. These audit techniques are applied in a general audit, so the audit evidence that has been collected will support the independent auditor's opinion. In investigative audits, the audit techniques are explorative, looking for "areas of work", or probing (eg in analytical reviews) and inland (eg in confirmation and documentation).

Tuankotta [11] stated that an investigative auditor and a forensic auditor use audit techniques that include the following:

1. Use of financial statement auditing techniques.

2. Utilization of taxation techniques

3. Tracing the traces of the flow of money.

4. Application of legal analysis techniques.

5. Utilization of investigative audit techniques in the procurement of goods.

6. Use of Computer Forensics.

7. Use of Interrogation Techniques.

8. Use of Undercover Operations.

9. Utilization of Whistleblowers.

From this explanation, it can be concluded that the investigative auditor must carry out the procedure in stages in carrying out an investigative audit for evidence of fraud. If the investigative auditor has carried out the above processes, then the auditor can be said to have adequate capabilities. 
Fraud Diamond Theory Fraud (Fraud) is an action that is generally done intentionally by someone with the aim of benefiting himself.

Fraud Diamonds:

1. Opportunity is an opportunity that causes actors to freely carry out their actions caused by weak internal control, indiscipline, weakness in accessing information, no audit mechanism \& apathy.

2. Pressure Pressure/Motive is something that drives people to commit fraud, which can be caused by lifestyle demands, helplessness in terms of finances, gambling behavior, trying to beat the system and job dissatisfaction.

3. Rationalization of perpetrators always seeks justification for their actions.

\section{RESEARCH METHODS}

\subsection{Population and Sample}

The population of this research is 33 local governments, namely districts/cities in North Sumatra Province. The research sample was carried out by census, that is, all of the population was used as a research sample to be observed based on the results of the examination of financial statements.

\subsection{Data Source}

The source of this research data is secondary data taken from various websites of BPK, BPKP, Central Statistics Agency in the form of General Allocation Funds, Special Allocation Funds, Regional Taxes while the Directorate General of Fiscal Balance (DJPK) of the Ministry of the Republic of Indonesia (http://www. djpk.kemenkeu.go.id) which publishes the APBD Realization Report.

\subsection{Research Variable}

The variables of this study include Forensic Accounting and Fraud. Scope of the definition of the variable is If the auditor already has this capability and carries out investigative audits and forensic audits in accordance with applicable procedures, the investigative audits carried out in the detection of white collar crimes will be effective. a. Predictors: (Constant), Investigative Audit, Forensic Accounting

b. Dependent Variable: Financial Fraud

\subsection{Data Analysis Technique}

Analysis of the research data with the regression equation, namely:

Fraud $=$ Forensic Accounting + Investigative Audit

Data analysis techniques performed include:

1. Using a comparative study of the data presented from the results of the audit of BPK's financial statements.

2. Retrieve data from searching from the BPK, BPKP, and DJPK Agency Webs

3. Discussing cases that occurred in the Government from the National Newspaper and Internet Media.

4. Provide a structured discussion based on the theory and results of previous research.

\section{RESULTS AND DISCUSSION}

\subsection{The results of the examination of the financial statements that have been carried out by the BPK in all districts of North Sumatra.}

There are 33 regencies in North Sumatra Province, including: Asahan, Batu Bara, Dairi, Deli Serdang, Humbang Hasundutan, Karo, Labuhanbatu, South Labuhanbatu, North Labuhanbatu, Langkat, Mandailing Natal, Nias, West Nias, South Nias, North Nias , Padang Lawas, North Padang Lawas, West Pakpat, Samosir, Serdang Bedagai, Simalungun Regency, South Tapanuli, Central Tapanuli, North Tapanuli, Toba Samosir, Binjai, Gunung Sitoli, Medan City, Padang Sidempuan City, Pematang Siantar City, Sibolga City, Tanjung Balai City, Tebing Tinggi City (bpk.go.id)

The Financial Statements that have been audited by the BPK for 33 Regencies of North Sumatra Province are as follows: 
1. The results of Fair Financial Statements with exceptions in several North Sumatra Regencies in 2017 to 2019 are:

a. Pematang Siantar Regency

b. West Pakpak Regency

c. Mandailing Natal Kabupaten

d. Padang Sidimpuan Regency

e. Central Tapanuli Regency

f. Labuhan Batu Regency

g. Nias District

h. South Nias Regency

i. Tanjung Balai District

j. North Nias Regency

2. The results of the Financial Statements audited without exception in 2019 were the Provinces of North Sumatra, Samosir, Langkat, Serdang Bedagai, Simalungun, Karo, North Labuhanbatu, Binjai, Gunung Sitoli, Sibolga, North Tapanuli, South Tapanuli, , South Labuhanbatu, North Padanglawas, Tebing Tinggi, Deli Serdang, Dairi, Toba Samosir, Coal, Asahan, Humbang Hasundutan, Padang Lawas, and West Nias (bpk.go.id)

3. The results of the analysis of the District and City Government Financial Statements that have been audited by the BPK show the results of the movement to the 2nd stage of change from Disclaiming an Opinion to Unqualified Unqualified is West Nias Regency. While those who are still moving to 1 stage, namely Fair with Exceptions, are Tebing Tinggi and Simalungun Regencies (bpk.go.id)

\subsection{Forensic Accounting}

PDIP General Chair Megawati Soekarnoputri highlighted regional heads in North Sumatra (North Sumatra) who, according to her, have been entangled in corruption cases. Megawati warned that candidates for regional heads who received recommendations from the PDI-P should not be involved in legal cases, let alone corruption. "Try, like North Sumatra. Try that, there were a lot of rengreng, please. Please think about it, please remember, how many governors were affected, how many mayors were affected. Everything is a legal matter. Let's see," said Megawati when giving directions after the announcement of PDIP recommendations to candidate pairs in 75 regional elections 2020, Tuesday [4]. So far, there are 13 regional heads from North Sumatra who have been caught in corruption cases. That number is only regional heads whose corruption cases are handled by the KPK. Here's the list:

1. Governor of North Sumatra Syamsul Arifin

2. Governor of North Sumatra Gatot Pujo Nugroho

3. Mayor of Medan Abdillah

4. Deputy Mayor of Medan Ramli

5. Nias Regent Binahati B Baeha

6. South Nias Regent Fahuwusa Laia

7. Pematangsiantar Mayor Robert Edison Siahaan

8. Mandailing Regent Natal Hidayat Batubara

9. Regent of Central Tapanuli Raja Bonaran Situmeang

10. Coal Regent OK Arya Zulkarnaen

11. Regent of Labuhanbatu Pangonal Harahap

12. Regent of Pakpak Bharat Remigo Yolando Berutu

13. Medan Mayor Dzulmi Eldin

From January 2020 to December 2020, Sahdar has monitored corruption cases that were revealed to the public and tried at the Corruption Court at the Medan District Court. Based on the results of monitoring carried out, there was a decrease in the number of corruption cases from previous years. In 2020, we noted that there were 83 Registered Cases that were heard at the Corruption Court at the Medan District Court. It is known that there has been a decrease in the number of cases being heard at the Tipikor Court at the Medan District Court, from which previously there were 79 corruption cases in 2018 (128 case registers), and 48 cases ( 87 registers) in 2019, while this year there were only 47 corruption cases ( 83 Case Register)," he said. The decline in corruption cases is thought to be due to the political year, so the number of handling cases and taking action against corruption cases is lower. Some of the cases that were tried this year we noted came from cases that had not been tried in the previous year. Some of them are cases that have been tried before but are undergoing development. Among other things, the bribery case of former North Sumatran Governor Gatot Pujo Nugroho and the case of Distance Education Management in South Nias. He further conveyed, from all the cases that have been tried, the number of perpetrators involved in corruption cases throughout 2020 was 95 people, including 53 dominated by ASN, 17 government partners, followed by 9 village officials, DPRD 
members 14 people and 1 regional head. This year there is one regional head who is on trial for being involved in a corruption case. This figure adds to the long list of corruption actors who come from regional heads. Where every year there is always a regional head who stumbles on a corruption case.

In addition to BPK and BPKP, there are also those who can carry out Forensic Accounting, namely the Corruption Eradication Commission (KPK) and ICW (Indonesian Corruption World) which have a background in Accounting and Auditing.

Cases that show indications of corruption or fraud can be followed up with forensic accounting which can be carried out by the BPK and can cooperate with the KPK. So that cases of fraud or corruption do not reoccur and serve as lessons for regional officials to work seriously and comply with the regulations set by the Government.

Forensic Accounting is very necessary if it is suspected that fraud has occurred, Forensic Accounting is carried out to support the Court, to strengthen evidence and ensure an incident that will be submitted to the court.

\subsection{Investigation Audit}

An investigative audit is an audit search by focusing on accounts that have the potential to lead to fraud. Investigation Audits can be carried out by BPK, BPKP, Regional Inspectorate Team, and Bawasda. Some of the Materials for Investigation Audits in North Sumatra are

a. Deputy Chairman of the Supreme Audit Agency (BPK) Agus Joko Pramono said BPK participated in eradicating corruption through examination of financial management in various Ministries and Central Government Institutions, Regional Governments and BUMN. With the existence of financial audits, performance checks, inspections with a specific purpose to explore certain things, then we are actually accessing which control system, which risk assessment, from the system that is already running, which encounters obstacles or has problems, according to Deputy BPK Agus Jokok Pramono in the Anti-Corruption Workshop entitled "The Detection and
Prevention of Corruption that can be monitored. Agus also stated that financial audits, performance, and audits with specific objectives were integrated so that BPK could project the risks of fraud or processes that deviate from standards, in the future. A weak internal control system in an institution can be detected to improve the internal control system.

b. Focusing on Regional Budgets and Expenditures with Regional Expenditures.

Regional budgets and expenditures such as:

\section{Unconditional Grants}

Unconditional grants are transfers to local governments that are not accompanied by certain ties or conditions in the sense that the region can use or allocate it to the uses desired by the region concerned. The main feature of this transfer is that the regions have full power to use the transfer funds according to their own considerations or according to the rules of what are the priorities of their regions. Unconditional Grants itself consists of two, namely the General Allocation Fund and Revenue Sharing Fund.

\section{Special Allocation Fund}

In Law No. 33 of 2004 concerning the financial balance between the central government and regional finance which states that "special allocation funds are funds sourced from APBN revenues allocated to certain regions with the aim of helping fund special activities which are regional affairs and in accordance with national priority."

\section{Local Tax}

Law No. 34 of 2000 states that "Local taxes are mandatory contributions made by individuals or entities to the region without balanced compensation which can be imposed based on applicable laws and regulations that can be used to finance the implementation of regional government and regional development."

\section{Gross Regional Domestic Product (GDP)}

Gross regional domestic product is the amount of added value produced by all business units in a certain area or region, or is the total value of final goods and services produced by all units of 
economic activity in a region or region. in a certain period".

\section{Regional Shopping}

Regional expenditures are all expenditures from the Regional General Treasury Account which are recognized as deductions from the value of net assets, which are regional obligations in one fiscal year which will not be repaid by the Regions. The amount of regional expenditure can be seen in the Regional Revenue and Expenditure Budget Report (APBD) in the Regional Expenditure section.

The results of the Audit of Financial Statements conducted by the BPK in 2019 showed that the opinion given by the BPK to several Regency Governments in North Sumatra showed that unqualified opinion report. For 2020, the researcher has not received data regarding the results of the examination of financial statements from BPK Website or BPKP Website

Forensic Accounting Models and Investigative Audits will more quickly assist in committing fraud. The Investigative Audit and Forensic Accounting will be submitted to the Court in the form of a Forensic Audit which has combined the findings of the Regional Inspectorate Investigation, BPKP and BPK stating that there was fraud as evidence to be brought to the Police and Prosecutors to be followed up legally and quickly.

\section{CONCLUSIONS AND SUGGESTION}

\subsection{Conclusions}

Based on the discussion and explanation above, the qualitative research that the researchers observed, the conclusions drawn are:

a. The results of the Audit of District Government Financial Statements in North Sumatra which consist of 33 Regencies in North Sumatra show that many of these frauds occurred in 2017 to 2018 which mostly showed reasonable exceptions and there were 3 districts that did not provide an opinion in the financial statements.

b. In 2020, North Sumatra ranks highest in corruption cases in Sumatra where the results of the audit of the district government's financial statements in North Sumatra in 2019 still have many BPK Audit Reports that show reasonable with exceptions so that this results in many frauds being found in several Sumatran districts. In 2020 Researchers have not been able to get information from the BPK regarding the Financial Statement Audit Results from the website they provide.

c. Investigative Audit is an Audit Search that focuses on items or estimates suspected of showing Fraud.

d. The Forensic Audit has combined the findings of the Regional Inspectorate Investigation, BPKP and BPK stating that fraud was brought to the Police and Prosecutors for legal and appropriate follow-up and accompanied by a Forensic Audit Report.

e. In 2020, North Sumatra Province is the province with the highest level of fraud from the Provinces of South Sumatra and West Sumatra, this is indicated by the existence of an Audit Report of Financial Statements conducted by BPK or Public Accountants mandated by BPK.

f. In addition to Bawasda or the Regional Inspectorate or the Internal Auditor from the Regency Government.

g. Availability of secondary data can be obtained from BPS, BPK, BPKP and BPS as well as the Directorat Jenderal Perimbangan Keuangan (DJPK).

\subsection{Suggestion}

From the explanation of the discussion and search based on secondary data, suggestions can be given, including:

a. Bawasda or the Regional Inspectorate can build and provide technology-based data that can be downloaded by various parties such as researchers, students who will write theses, BPKP and BPK so that data is taken primary or secondary.

b. The LAKIP data is recommended for every Regional Government to regularly upload quarterly, semi-annually and annually submitted 
openly which can be cross-checked equally to the Central Statistics Agency (BPS) and DJPK.

\section{REFERENCES}

[1] Ayu, Dymita. Persepsi Mahasiswa Terhadap Peran Akuntansi Forensik sebagai Pencegahan Fraud di Indonesia, Universitas Negeri Yogyakarta. 2012.

[2] Badan Pemeriksa Keuangan Reupblik Indonesia. Ikhtisar Hasil Pemeriksaan Semester I Tahun 2016. September 2016. Jakarta. 2016.

[3] Badan Pemeriksa Keuangan Reupblik Indonesia. Ikhtisar Hasil Pemeriksaan Semester II Tahun 2016. Maret 2017. Jakarta. 2017.

[4] Baca artikel detiknews, "Disorot Megawati, Ini 13 Kepala Daerah di Sumut yang Terjerat Korupsi" selengkapnya https://news.detik.com/berita/d5128474/disorot-megawati-ini-13-kepaladaerah-di-sumut-yang-terjerat-korupsi

[5] Bologna, G. Jack and Robert. J. Linquisdt. Fraud Auditing and Forensic Accounting : New Tools and Techniques, by Jack Bologna and Robert J. Lindquist, John Wiley \& Sons, New York, Wiley \& Sons. 1987.

[6] Clinard and Quinney. Criminal Behavioral System A Typology. New York: Holt, Rinehart and Wistons Inc. 1967.

[7] Crumbley, D. Larry., Forensic and Investigative Accounting. USA: Holt, Rinehart and Wistons Inc. 2005.

[8] Digabriele, James A. An empirical investigation of the relevant skill of forensic accountants. Journal of Education for Business. 2008.

[9] Fauzan, et all., Pengaruh Akuntansi Forensik dan Audit Investigasi Terhadap Pengungkapan Fraud, UNISBA E-Journal. 2015.

[10]K. H. Spencer Pickett dan Jennifer Pickett. Financial Crime Investigation and Control. New York: John Wiley \& Sons. 2002.

[11] Tuanakotta, Theodorus M. Akuntansi Forensik dan Audit Investigatif. Jakarta: Salemba Empat. 2010 . 